\title{
Hybridization techniques and frost tolerance studies in intraspecific hybrids of Eucalyptus globulus Labill
}

\author{
M.H. Almeida ${ }^{1}$ and A.C. Leal 2 \\ 1 Instituto Superior de Agronomia, Forestry Dept., Lisbon, and \\ ${ }^{2}$ CELBI (Celulose Beira Industrial), Quinta do Furadouro, Obidos, Portugal
}

\section{Introduction}

Hybridization techniques have been developed since 1985, in a clonal seed orchard of $E$. globulus located in the central coastal area of Portugal. The objective was to enlarge the genetic base of the E. globulus population. In intraspecific hybrids, seed characteristics and growth were evaluated in the field and frost tolerance studies were made in a temperature-controlled chamber.

\section{Materials and Methods}

\section{Controlled pollination}

Controlled pollination techniques were developed in grafted material in 3 clones (27 trees). A total of 2327 flowers were pollinated. At anthesis, the operculum was removed manually and emasculation was done with a blade. The flowers were then isolated with unwoven terylene bags. Optimum stigma receptivity, shown by an exudate, was determined using controlled pollinations made over $2 \mathrm{~d}$ intervals, from $\mathrm{d} \mathbf{4}$ to d 14, in groups of 60 flowers. In each group, the proportion of flowers with stigmatic exudations was recorded. Controlled pollinations were made with a brush.

Seed production, rate of germination and survival of seedlings were evaluated in cross-, selfand open-pollinated flowers, using 100 seeds from 20 capsules per seed type. Some of these seeds were planted in the field and evaluated for growth.

\section{Frost tolerance}

Twelve uniform seedlings from each of 3 full-sib families were subjected to $8 \mathrm{~h}$ of light at close to $25^{\circ} \mathrm{C}$ outdoor $/ 16 \mathrm{~h}$ of dark at $4^{\circ} \mathrm{C}$ in a cold room. A second comparable group of seedlings remained outdoors under favorable growth conditions and after $3 \mathrm{wk}$, the 2 groups were randomized and subjected to either: 1) outdoor conditions (control), 2) $-3.1^{\circ} \mathrm{C}$ or 3$)-4.3^{\circ} \mathrm{C}$.

The temperature was lowered at a rate of $1^{\circ} \mathrm{C} / \mathrm{min}$ to $2^{\circ} \mathrm{C}$, and thereafter at $0.1^{\circ} \mathrm{C} / \mathrm{min}$ to the desired frost temperature which remained constant for $2 \mathrm{~h}$. The rate of warming was the same as the rate of cooling. Damage to whole seedlings was evaluated as the number of survivors after 1 and $4 \mathrm{wk}$, and as the increase in height after 4 wk.

The experimental design was a 3 stage nested design (family/hardening/temperature) with 4 replicates.

\section{Results}

Controlled pollination (Fig. 1 and Table I)

\section{Frost tolerance}

The analysis of variance showed significant differences only between tempera- 


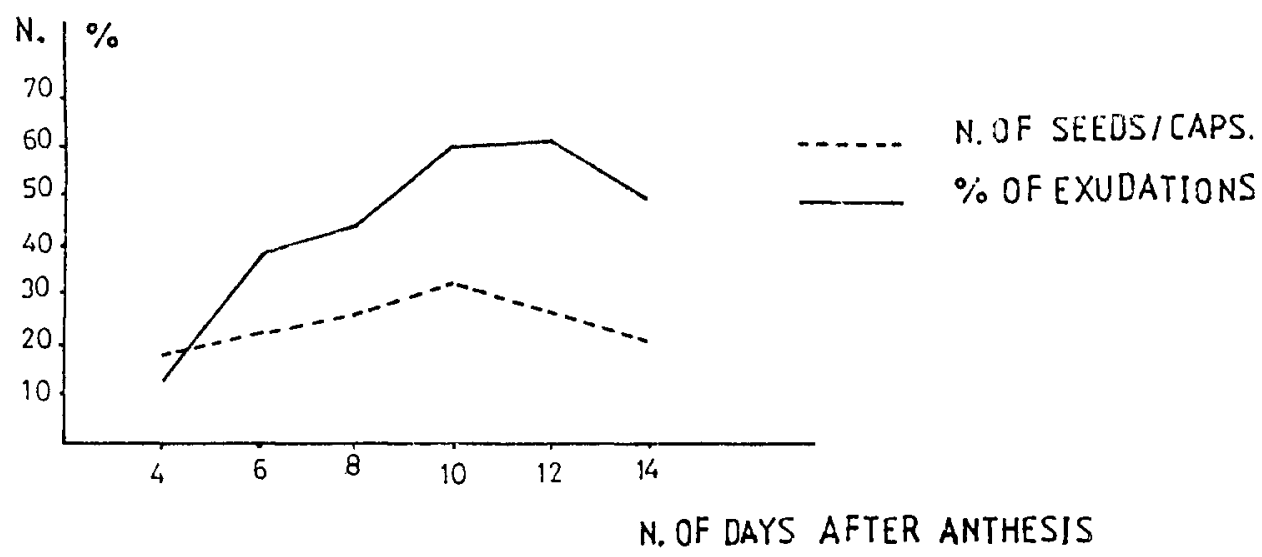

Fig. 1. Relation between mean number of stigmatic exudations and mean seed production in 3 clones.

tures. The frosted plants either died or were damaged.

\section{Conclusions}

Controlled pollination

Maximum stigmatic receptivity, related to maximum seed production occurs 8-12 days after anthesis, when a stigmatic exudate is visible as a drop of fluid.

The cross-pollinated seed lot was clearly the best for the variables: seed production/capsule, rate of germination and seedling survival, and the self-pollinated lot was clearly the worst. This trend was also found in subsequent growth in the field.
Table I. Seed production, rate of germination and survival of seedlings from cross-, openand self-pollinated flowers in one family.

\begin{tabular}{llll}
\hline Pollination & $\begin{array}{l}\text { Seed } \\
\text { productcaps }\end{array}$ & $\begin{array}{l}\text { Germ. } \\
(\%)\end{array}$ & $\begin{array}{l}\text { Seedling } \\
\text { survival (\%) }\end{array}$ \\
\hline Cross & 17 & 87 & 31 \\
Open & 4 & 78 & 15 \\
Self & 2 & 17 & - \\
\hline
\end{tabular}

\section{Frost tolerance}

These results suggest that hardening had no effect on frost resistance in the crosses used (Table II). Cold treatment reduced the increase in height after 4 wk in all families by causing damage to the shoot apices.

Table II. Effects of hardening on height growth after 4 wk.

\begin{tabular}{llllllll}
\hline Family & \multicolumn{3}{c}{ Hardened } & \multicolumn{5}{c}{ Not hardened } \\
\cline { 2 - 3 } \cline { 6 - 8 } & control & $-3.1^{\circ} \mathrm{C}$ & $-4.3^{\circ} \mathrm{C}$ & & control & $-3.1^{\circ} \mathrm{C}$ & $-4.3^{\circ} \mathrm{C}$ \\
\hline 1 & 1.424 & 0.000 & 0.000 & & 1.354 & 0.000 & 0.000 \\
2 & 1.350 & 0.484 & 0.356 & & 1.290 & 0.209 & 0.000 \\
3 & 1.361 & 0.333 & 0.084 & & 1.346 & 0.103 & 0.000 \\
\hline
\end{tabular}

